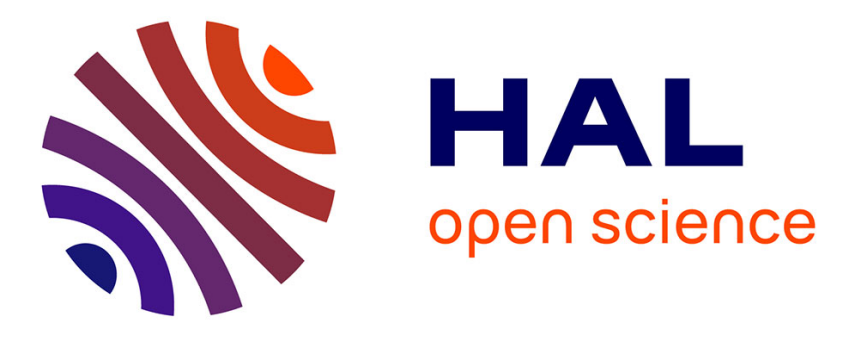

\title{
Influence of food on the assimilation of essential elements (Co, Mn, and Zn) by turbot (Scophthalmus maximus)
}

Simon Pouil, Michel Warnau, François Oberhänsli, Jean-Louis Teyssié, Paco Bustamante, Marc Metian

\section{To cite this version:}

Simon Pouil, Michel Warnau, François Oberhänsli, Jean-Louis Teyssié, Paco Bustamante, et al.. Influence of food on the assimilation of essential elements (Co, Mn, and Zn) by turbot (Scophthalmus maximus). Marine Ecology Progress Series, 2016, 550, pp.207 - 218. 10.3354/meps11716 . hal01377877

\section{HAL Id: hal-01377877 \\ https://hal.science/hal-01377877}

Submitted on 7 Oct 2016

HAL is a multi-disciplinary open access archive for the deposit and dissemination of scientific research documents, whether they are published or not. The documents may come from teaching and research institutions in France or abroad, or from public or private research centers.
L'archive ouverte pluridisciplinaire HAL, est destinée au dépôt et à la diffusion de documents scientifiques de niveau recherche, publiés ou non, émanant des établissements d'enseignement et de recherche français ou étrangers, des laboratoires publics ou privés. 


\section{Influence of food on the assimilation of essential elements (Co, Mn \& Zn) by turbot (Scophthalmus maximus)}

Simon Pouil ${ }^{\mathrm{a}, \mathrm{b}}$, Michel Warnau ${ }^{\mathrm{a}}$, François Oberhänsli ${ }^{\mathrm{a}}$, Jean-Louis Teyssiéa ${ }^{\mathrm{a}}$, Paco Bustamante ${ }^{\mathrm{b}}$, $\operatorname{Marc~Metian~}^{\mathrm{a}}$

a International Atomic Energy Agency, Environment Laboratories, 4a, Quai Antoine Ier, MC-98000, Principality of Monaco, Monaco

b Littoral Environnement et Sociétés (LIENSs), UMR 7266, CNRS-Université de La Rochelle, 2 rue Olympe de Gouges, F-17000 La Rochelle, France

* Corresponding author: Dr Marc Metian

Radioecology Laboratory

IAEA Environment Laboratories

4a Quai Antoine 1er

MC-98000 Principality of Monaco

Telephone: +3779797 7217

E-mail: $\underline{\text { m.metian@iaea.org }}$ 


\begin{abstract}
Food is an important route of metal uptake in marine organisms and assimilation efficiency (AE) is a key physiological parameter that can be used to systematically compare the bioavailability of different metals from food. This parameter may be influenced by various factors, including diet. The present study aimed at examining the influence of diet on AEs of three essential metals (Co, $\mathrm{Mn}$ and $\mathrm{Zn}$ ) in the turbot, Scophthalmus maximus. The pulse-chase feeding method was used with three radiolabelled natural prey: fish, shrimp and ragworm. The results showed that AE was strongly influenced by the prey and the metal considered. However, the influence of these parameters on AE was variable and no general trend was observed. The AEs ranged between 5$43 \%$ for Co, 23-44\% for Mn and 17-32\% for Zn. Results suggest that relationships between metal distribution in the prey (at tissue and subcellular levels) and bioavailability to predator fish is not obvious as previously assumed based on marine organisms feeding on unicellular or simple pluricellular organisms. Finally, we modelled how S. maximus is accessing foodborne essential elements using experimentally-derived parameters, the concentration of these elements in prey, and different data on stomach contents from wild turbot. Results emphasize the importance of crustaceans in the nutrition of turbot showed that this taxa is generally the most important source of essential metals for turbot although in some cases polychaetes can make a high contribution to dietary Co and Mn uptake.
\end{abstract}

Running page head: Assimilation of essential elements in turbot

$\underline{\text { Key words: }}$ Marine fish; Assimilation efficiencies; Natural prey; Depuration; Metals; Nutrition 


\section{Introduction}

Fish accumulate metals through different pathways (e.g. Warnau \& Bustamante 2007; Dutton \& Fisher 2011). Over the last decade, food has been increasingly identified as a pathway of major importance for metal intake in fish (Xu \& Wang 2002; Mathews \& Fisher 2009). However, despite a growing understanding of trophic transfer mechanisms, few studies have focused on the influence of the diet on the assimilation of essential metals in these organisms (Baudin \& Fritsch 1989; Garnier-Laplace et al. 2000; Bury et al. 2003).

Essential metals such as $\mathrm{Co}, \mathrm{Mn}$ and $\mathrm{Zn}$, are metabolically required; they are part of the functional groups of various enzymes, play a structural role in respiratory pigments and metalloenzymes, and can act as activating co-factors for various proteins (see e.g. Simkiss 1979; Williams 1981). Fish health can be optimal if essential metals are present in sufficient amounts in their tissues: depletion in these elements can provoke pathological impairments and/or physiological alterations and excess of essential elements can provoke toxic effects (e.g. Förstner \& Wittmann 1983).

One critical parameter for understanding metal trophic transfer in fish is the assimilation efficiency (AE) of the metal from ingested food. If derived under controlled experimental conditions, $\mathrm{AE}$ is a first-order physiological parameter that can be compared quantitatively among different metals, organisms, food types, or environmental conditions (Wang \& Fisher 1999).

The main objective of the present study was to investigate the influence of the diet on essential metal assimilation by $S$. maximus. We compare the $\mathrm{AE}$ of three essential metals (Co, $\mathrm{Mn}$, and $\mathrm{Zn}$ ) in a marine predatory fish, the turbot Scophthalmus maximus, fed on three different natural prey (fish, shrimp and ragworm) using radiotracer techniques. In order to better understand 
assimilation processes for the aforementioned essential metals, depuration kinetics were determined and AEs estimated after a single feeding with radiolabelled prey (pulse-chase feeding methodology; e.g. Warnau et al. 1996; Metian et al. 2010). Relationships between metal fractioning in prey (tissue and subcellular levels) and metal AEs in their predators have been shown for invertebrates and planktivorous fish (Reinfelder \& Fisher, 1994; Wallace \& Lopez, 1996) but not yet for fish fed with complex pluricellular prey. Therefore, tissue and subcellular distribution of essential elements was characterized in order to assess possible influence on AEs in turbot.

Finally, AE results were combined with stable isotope analyses in the selected prey and with the natural diet of turbot to develop a model that was used to estimate the relative contribution of each prey in the dietary intake of metals.

\section{Materials and Methods}

\subsection{Origin and acclimation of organisms}

In January 2014, one hundred juvenile turbot Scophthalmus maximus were purchased from a fish farm (France Turbot, France) and shipped to the International Atomic Energy Agency premises in the Principality of Monaco. Fish were acclimated to laboratory conditions for 21 days (open circuit, 500-L aquarium; water renewal: $100 \mathrm{~L} \mathrm{~h}^{-1}$; $0.45 \mu \mathrm{m}$ filtered seawater; salinity: 38 p.s.u.; temperature: $15 \pm 0.5^{\circ} \mathrm{C} ; \mathrm{pH}: 8.0 \pm 0.1$; light/dark: $\left.12 \mathrm{~h} / 12 \mathrm{~h}\right)$. During the acclimation period, the fish were fed a daily ration of $2 \%$ of their biomass with $1.1-\mathrm{mm}$ pellets (proteins: $55 \%$ and lipids: 12\%; Le Gouessant, France).

In order to investigate the influence of the diet on essential metal assimilation by $S$. maximus, three different natural prey were used: fish (seabream Sparus aurata), shrimp (common prawn 
Palaemon serratus) and ragworm (estuary ragworm Hediste diversicolor). Fish were obtained from the hatchery "Poissons du Soleil", France, shrimp were purchased from "Poissons Vivants", France, and ragworms were purchased from fishing bait seller "Normandie Appâts", France. All prey were acclimated to the same laboratory conditions as the turbot for a minimum of two weeks prior to experiments. Shrimp and worms were fed a mix of fish feed and crushed mussels whereas juvenile fish were fed $300-\mu \mathrm{m}$ pellets (Biomar, France). Since body size (weight) is known to affect metal bioaccumulation in marine organisms (Boyden, 1974; Warnau et al., 1995; Hédouin et al. 2006), only prey individuals with homogeneous size were used for the experiments (S. aurata; 60-day-old hatchlings, approx. 1.5 to $2 \mathrm{~cm}$ in total length, $0.06 \pm 0.01 \mathrm{~g}$ wet weight wwt-), P. serratus, $0.58 \pm 0.11 \mathrm{~g}$ wwt and $H$. diversicolor, $0.82 \pm 0.14 \mathrm{~g}$ wwt).

\subsection{Nutritional characteristics and stable metals in prey}

Preliminary characterization of metal concentration and basic nutritional composition of the prey was carried out prior to radiolabelling. Protein content (using $\mathrm{N}$ content), percentage of dry matter (DM) and essential metal concentrations (Co, $\mathrm{Mn}$ and $\mathrm{Zn})$ were measured. To determine the amount of N, samples of food items $(n=3)$ were freeze-dried (FreeZone 18L Console Freeze Dry System, Labconco ${ }^{\circledR}$ ) before being manually crushed. Aliquots of 1 to $5 \mathrm{mg}$ were analysed using a vario EL CHN analyser, Elementar ${ }^{\circledR}$. For each food item, the protein content (expressed as $\%$ of dry matter) was estimated using conversion coefficients from $\mathrm{N}$ values (i.e. 5.58 for fish and 5.60 for the other prey; Tacon et al. 2009). Dry matter (DM) content was determined by drying the samples in a ventilated oven at $105^{\circ} \mathrm{C}$ for $24 \mathrm{~h}$.

For essential element analyses, samples ( $\mathrm{n}=3$ for each prey) of 250 to $1000 \mathrm{mg}$ were digested using $5 \mathrm{~mL}$ of $65 \% \mathrm{HNO}_{3}$ and $2 \mathrm{~mL}$ of $\mathrm{H}_{2} \mathrm{O}_{2}$. Acidic digestion was performed overnight at 
ambient temperature and then heated in a microwave for $40 \mathrm{~min}$, with a temperature increase to $190^{\circ} \mathrm{C}$ for $20 \mathrm{~min}$, followed by $20 \mathrm{~min}$ at $190^{\circ} \mathrm{C}(1600 \mathrm{~W})$. After the mineralization process, each sample was diluted to $50 \mathrm{~mL}$ with milli-Q quality water and an extra 1:5 dilution was prepared. Co and Mn were analysed by ICP-MS (iCAP Q ICP-MS, Thermo Scientific ${ }^{\circledR}$ ) and Zn by flame atomic absorption spectrometry (SpectrAA 220, $\operatorname{Varian}^{\circledR}$ ). A certified reference material (fish muscle, IAEA 407) was treated and analysed in the same way as the samples. Results were in good agreement with the certified values (Table 1). For each set of analyses, blanks were included in analytical batch. The detection limits were $\left(\mu \mathrm{g} \mathrm{g}^{-1} \mathrm{dwt}\right): 0.006(\mathrm{Co}, \mathrm{Mn})$ and 0.5 ( $\mathrm{Zn})$. All metal concentrations are given on a dry weight basis $\left(\mu \mathrm{g} \mathrm{g} \mathrm{g}^{-1} \mathrm{dwt}\right.$ ). For the shrimp, antennae, antennules, rostrum and telson were removed before analysis in accordance with experimental methodology (see section 2.3.2.).

\subsection{Experimental procedures}

\subsubsection{Radiolabelling of the prey}

Preparation of the radiolabelled prey was carried out by exposing them for 7-21 days in aerated 20-L aquaria. Radiotracers of high specific activity were purchased from Isotope Product Lab., USA $\left({ }^{57} \mathrm{Co}\right.$ as $\mathrm{CoCl}_{2}$ in $0.1 \mathrm{M} \mathrm{HCl},\left[\mathrm{T}_{1 / 2}\right]=271.8$ days; ${ }^{54} \mathrm{Mn}$ as $\mathrm{MnCl}_{2}$ in $0.5 \mathrm{M} \mathrm{HCl}$, $\left[\mathrm{T}_{1 / 2}\right]$ $=312.2$ days; ${ }^{65} \mathrm{Zn}$ as $\mathrm{ZnCl}_{2}$ in $0.1 \mathrm{M} \mathrm{HCl},\left[\mathrm{T}_{1 / 2}\right]=243.9$ days). Seawater was spiked with the radiotracers (nominal activity of $0.5 \mathrm{kBq} \mathrm{L}^{-1}$ per isotope for fish and shrimp exposures and $1 \mathrm{kBq}$ $\mathrm{L}^{-1}$ per isotope in the case of ragworm). In terms of stable metal concentrations, these additions corresponded to $0.2-0.4 \mathrm{pmol} \mathrm{L}^{-1}$ for $\mathrm{Co}, 3.7-7.4 \mathrm{pmol} \mathrm{L}^{-1}$ for $\mathrm{Mn}$ and 220-440 $\mathrm{pmol} \mathrm{L}^{-1}$ for $\mathrm{Zn}$, i.e. concentrations that are lower than the background concentrations of these metals in open sea (Bruland 1983). Small volumes $(10 \mu \mathrm{L})$ of the diluted radiotracer solution were added to the 
aquaria and no change in $\mathrm{pH}$ was detectable in the aquarium (close circuit) after tracer addition. Seawater was regularly renewed and spiked daily to keep the activity as constant as possible. Activity of the metal tracers in seawater was checked daily, before and after each seawater renewal, to determine time-integrated activities (Warnau et al. 1996; Rodriguez y Baena et al. 2006). Prey were fed after each seawater renewal. For shrimp exposure, each organism was kept individually during the whole duration of the experiment in a cylindrical plastic container (drilled to allow for free water circulation) in order to avoid cannibalism (e.g. during moulting) and to facilitate individual recognition. For the ragworm exposure, the walls of the aquarium were obscured and plastic tubes were added as artificial burrows.

\subsubsection{Exposure of turbot via radiolabelled prey}

Three sets of experiments were conducted for each prey. For each set, 8 to 15 juvenile turbot $(11.17 \pm 4.76 \mathrm{~g})$ were transferred in an aerated, open circuit, 70-L aquarium. The number of turbot depended on the amount of contaminated prey available. Slits cut into the fins were used to facilitate individual recognition. One week before the exposure to radiolabelled diet, fish were fed daily with the non-labelled prey to acclimate them to this diet. Each experiment consisted of a single feeding of fish with radiolabelled diet (see e.g. Metian et al. 2010). Turbot were fed $30 \mathrm{~min}$ ad libitum with freshly killed prey; uneaten diets were removed after the 30-min feeding. To facilitate ingestion, shrimp were cut into pieces and antennae, antennules, rostrum and telson removed. After the 30-min feeding, individual fish were whole-body $\gamma$-counted alive and then placed in a new aquarium with flowing seawater conditions (parameters as previously described) to follow subsequent metal depuration. During depuration, fish were fed daily with non-labelled pellets (2\% of their biomass, Biomar, 2014) to keep consistent digestive physiology amongst all individuals. During and after the labelled feeding, an additional turbot was placed in each 
aquarium to assess any possible radiotracer recycling from seawater due to leaching from the radiolabelled food or, later on, from fish depuration. After radiolabelled feeding, all the fish (including control individuals) were regularly radioanalysed to follow the radiotracer depuration kinetics over 21 days. After each counting fish were moved to another 70-L aquarium with clean water.

\subsubsection{Radiotracer compartmentalization in prey}

Radiolabelled fish $(n=3)$ and shrimp $(n=3)$ were dissected to isolate the hard body parts (skeleton and cuticle) that are assumed less digestible for predators (Reinfelder \& Fisher 1994). Samples were radioanalyzed to quantify the percentage of activity sequestered in these body parts (i.e. skeleton and cuticle).

Distribution of radioelements between the soluble and insoluble fractions was determined in four individuals of each species of prey according to a method adapted from Bustamante and Miramand (2005). This method allows quantification of metals associated with the soluble fraction of the prey (i.e. cytosol; Wallace \& Lopez 1996; Bustamante \& Miramand 2005). Briefly, 4 contaminated prey stored at $-80^{\circ} \mathrm{C}$ were crushed and tissue was homogenized (T25 Ultra-Turrax Basic, IKA ${ }^{\circledR}$ ) in around 10 volumes of TRIS-HCl buffer $0.02 \mathrm{M}$ sucrose $0.25 \mathrm{M}$ with $1 \mathrm{mM}$ PMSF (phenylmethylsulfonylfluoride, as protease inhibitor) and $5 \mathrm{mM}$ DTT (dithiothreitol, as reducing agent), at $\mathrm{pH}$ 8.06. The homogenates were centrifuged at $45000 \mathrm{G}$ for $2 \mathrm{~h}$ at $4^{\circ} \mathrm{C}$ (Sorvall Evolution RC Superspeed Centrifuge, Sorvall instruments ${ }^{\circledR}$ ) to separate cytosol (i.e. the soluble fraction) from the cellular debris, the organelles and the metal-rich granules (i.e. the insoluble fraction; Fig. 1). Aliquots of each fraction obtained were 
radioanalyzed in order to determine the radiotracer's activities. The same procedure was repeated over time for each prey.

\subsection{Radioanalysis}

The radioactivity of the tracers was measured using a high-resolution $\gamma$-spectrometer system composed of 5 Germanium - N or P type - detectors (EGNC 33-195-R, Canberra ${ }^{\circledR}$ and Eurysis ${ }^{\circledR}$ ) connected to a multi-channel analyser and a computer equipped with a spectra analysis software (Interwinner 6, Intertechnique $^{\circledR}$ ). The radioactivity in living organisms and samples was determined by comparison with standards of known activity and of appropriate geometry (calibration and counting). Measurements were corrected for background and physical radioactive decay. Living organisms were placed in counting tubes filled with clean seawater during the counting period. The counting time was adjusted to obtain a propagated counting error less than 5\% (e.g. Rodriguez y Baena et al. 2006). In the case of live turbot, the counting time varied between 25 and $60 \mathrm{~min}$ in order to maintain fish health and ensure normal behaviour.

\subsection{Data treatment and statistical analysis}

Depuration kinetics were fitted using non-linear model. Depuration of radiotracers was expressed as the percentage of remaining radioactivity (radioactivity at time $\mathrm{t}$ divided by the initial radioactivity measured in the organism at the beginning of the depuration period; Warnau et al. 1996). The depuration kinetics of the radiotracers were best fitted using a simple exponential model including a constant (eq. 1). Decision was based on F-test and examination of residuals:
$A_{t}=A_{0 s} \cdot e^{-k_{e s} t}+A E$
(eq. 1) 
where $A_{t}$ and $A_{0 s}$ are the remaining activities (\%) at time $t(d)$ and 0 , respectively; $k_{e s}$ is the depuration rate constant $\left(\mathrm{d}^{-1}\right)$ and $\mathrm{AE}$ is the assimilation efficiency (\%). The first component represents the depuration kinetics of the radiotracer fraction that is weakly associated with the organisms and rapidly eliminated (the subscript $s$ standing for short-lived), whereas the second component refers to the proportion of the radiotracer ingested with food that is actually assimilated by the organism (Warnau et al. 1996). For the short-lived component, a biological half-life can be calculated $\left(\mathrm{T}_{\mathrm{b} 1 / 2}\right)$ from the corresponding depuration rate constant according to the relation $\mathrm{T}_{\mathrm{b} 1 / 2 \mathrm{~s}}=\ln 2 / \mathrm{k}_{\mathrm{es}}$. Model constants and their statistics were estimated by iterative adjustment of the model and Hessian matrix computation, respectively, using the non-linear curve-fitting routines in the Statistica ${ }^{\circledR}$ software 7.0.

Statistical comparisons between the three different feeding experiments were conducted using individual depuration kinetics of each element: individual parameters ( $\mathrm{k}_{\mathrm{es}}$ and $\left.\mathrm{AE}\right)$ were obtained using the best fitting model at the global scale (eq. 1) to the data of each individual. Then differences between these parameters were tested using Kruskall-Wallis and Siegel \& Castellan non-parametric tests. The same statistical tests were used to compare the bioavailability of metals in the different prey. The level of significance for statistical analyses was always set at $\alpha=0.05$. All the statistical analyses were performed using R software 3.0.1 (R Development Core Team 2014).

A model was developed and used to estimate the relative contribution of each prey to the metal intake from food in wild turbot. The model assessing these contributions for each studied essential elements was determined using the following equations:

$$
\begin{aligned}
& C_{p 1}=\sum\left(A E_{P 1} * Q_{p 1} * I R * O_{p 1} * B W\right) \\
& C_{r 1}=\left(C_{p 1} / \sum C_{p}\right) * 100
\end{aligned}
$$


where $C_{p}\left(\mu \mathrm{g} \mathrm{d}^{-1}\right.$; wwt) is the amount of metal from one prey retained by the turbot (eq. 2$)$. This value was, then, expressed in percentage of total metal intakes from food (eq. 3). $\mathrm{AE}_{\mathrm{p}}$ is the assimilation efficiency (\%) estimated using (eq. 1); $\mathrm{Q}_{\mathrm{p}}\left(\mu \mathrm{g} \mathrm{\textrm {g } ^ { - 1 }}\right.$ wwt) is the stable metal concentration in prey; IR ( $\%$ of body weight $\left.\mathrm{d}^{-1}\right)$ is the ingestion rate for fish (range of values used in the literature: 0.1 to $10 \%$; Xu \& Wang 2002); $\mathrm{O}_{\mathrm{p}}(\%)$ is the occurrence of prey in natural diet estimated by stomach contents analysis (Sparrevohn et al. 2008; Florin \& Lavados 2010) and BW (g wwt) is the average body weight of the turbot used in this study. All the values are expressed on a wet weight basis, using conversion from percentage of dry matter provided in Table 2.

In order to better capture a certain degree of variability for the trophic transfer of essential elements to the turbot that can occur in the field, 3 scenarios covering 3 different situations were created. Using the model previously described, these scenarios were implemented on the basis of 3 different diet compositions reported from field surveys (Florin \& Lavados 2010; Sparrevohn et al. 2008). For each of these diets, 3 distinct values were assigned for the ingestion rate of the turbot, the concentration of essential elements in the prey and the turbot AE for the 3 elements studied (IR, Q and AE; details are provided in Table 2). Briefly, scenario "low" corresponded to the inclusion into the model of minimal values of these parameters found in the present paper $(\mathrm{Q}$ and AE) or in the literature (IR; Xu \& Wang 2002) whereas maximum and average values of the same parameters were respectively used in "high" and "medium" scenarios.

\section{Results}

\subsection{Nutritional characteristics and stable metal concentration in prey}

Essential element concentrations and nutritional characteristics estimated of the different food items are given in Table 2. Although this corresponds to a rough estimate of these characteristics 
( $n=3$ for each prey), ragworms were the prey with the highest levels for all studied essential elements (Co, Mn and $\mathrm{Zn})$. For example, Co concentrations reached $2.21 \pm 0.82 \mu \mathrm{g} \mathrm{g}^{-1} \mathrm{dwt}$ in ragworms vs. $0.08 \pm 0.01 \mu \mathrm{g} \mathrm{g}^{-1} \mathrm{dwt}$ in shrimp and $0.11 \pm 0.01 \mu \mathrm{g} \mathrm{g}^{-1} \mathrm{dwt}$ in fish (Table 2). However, ragworms were less nutritious than fish and shrimp, with 5\% of protein in dry matter compared to $12 \%$ and $16 \%$, respectively (Table 2 ).

\subsection{Compartmentalization of radiotracers in prey}

\subsubsection{Body distribution}

After radiolabelling ${ }^{57} \mathrm{Co}$ and ${ }^{65} \mathrm{Zn}$ were mainly distributed in the soft parts of fish and shrimp (i.e. whole-body activity minus activities measured in skeleton or cuticle; respectively, $89 \pm 3 \%$ and $60 \pm 7 \%$ for $\mathrm{Co}$ and $78 \pm 3 \%$ and $63 \pm 6 \%$ for Zn; Fig. $2 \mathrm{~A}$ ). In contrast, storage of ${ }^{54} \mathrm{Mn}$ depended on the considered prey: for fish, this element was mainly concentrated in the soft parts of body (64 $\pm 8 \%)$ whereas soft parts of shrimp contained a smaller proportion of Mn $(29 \pm 8 \%)$.

\subsubsection{Subcellular distribution}

The majority of ${ }^{57} \mathrm{Co}$ taken up by the prey was located in the soluble fraction with a proportion ranging between 63 to $87 \%$. The highest proportion $(87 \pm 2 \%)$ was measured in the soluble fraction of fish whereas, for shrimp, the soluble fraction contained $63 \pm 7 \%$ of Co body burden (Fig. 2B). ${ }^{54} \mathrm{Mn}$ was mainly distributed in the insoluble fraction of shrimp and fish with respectively $91 \pm 6 \%$ and $88 \pm 6 \%$. On the other hand, for ragworms, ${ }^{54} \mathrm{Mn}$ was mainly ( $57 \pm 7 \%$ ) present in the soluble fraction (Fig. 2B). The subcellular compartmentalization of ${ }^{65} \mathrm{Zn}$ in the different prey was variable. In fish and ragworms, most of ${ }^{65} \mathrm{Zn}$ was located in the soluble fraction $(\sim 60 \%)$ whereas it was distributed equally between the soluble and insoluble fractions of shrimp. 


\subsection{Effects of diet on metal assimilation}

To evaluate the influence of diet on metal assimilation in S. maximus, depuration kinetics of the three essential metals were followed after a pulse-chase feeding, using radiolabelled food items. The activity level of each element in each prey was measured prior to the feeding: the average activities were $50 \mathrm{~Bq}^{57} \mathrm{Co} \mathrm{g}^{-1}$ wwt, $19 \mathrm{~Bq}^{54} \mathrm{Mn} \mathrm{g}^{-1}$ wwt and $67 \mathrm{~Bq}^{65} \mathrm{Zn} \mathrm{g}^{-1}$ wwt in fish; $22 \mathrm{~Bq}$ ${ }^{57} \mathrm{Co} \mathrm{g}^{-1}$ wwt, $13 \mathrm{~Bq}{ }^{54} \mathrm{Mn} \mathrm{g}^{-1}$ wwt and $144 \mathrm{~Bq}^{65} \mathrm{Zn} \mathrm{g}^{-1}$ wwt in shrimp without antenna, antennules, rostrum and telson, and $20 \mathrm{~Bq}^{57} \mathrm{Co} \mathrm{g}^{-1} \mathrm{wwt}, 7 \mathrm{~Bq}^{54} \mathrm{Mn} \mathrm{g}^{-1}$ wwt and $250 \mathrm{~Bq} \mathrm{~g}^{-1}$ wwt of ${ }^{65} \mathrm{Zn}$ in ragworm.

Whole-body depuration kinetics of ${ }^{57} \mathrm{Co},{ }^{54} \mathrm{Mn}$, and ${ }^{65} \mathrm{Zn}$ in turbot were always best fitted by a two-phase model (simple-exponential model and a constant; Fig. 3 and Table 4; R ${ }^{2}$ : 0.76-0.98). The assimilation efficiency (AE) and depuration rate of the three radiotracers depended both on the food and metal considered. The major fraction (53-95\%) of the three elements was rapidly lost $\left(\mathrm{Tb}^{1} / 2 \mathrm{~S}<1.4 \mathrm{~d}\right)$ regardless of which prey had been ingested.

Estimated ${ }^{57} \mathrm{Co} \mathrm{AE}$ varied significantly $(\mathrm{p}<0.05)$ according to the prey type (Table 5). Indeed, ${ }^{57} \mathrm{Co}$ was poorly assimilated by turbot when fed with radiolabelled ragworms $(\mathrm{AE}=5.1 \pm 1.1 \%)$. Assimilation was elevated when fish were fed with juvenile fish $(\mathrm{AE}=43.1 \pm 12.0 \%)$ and an intermediate situation was observed when they were fed with shrimp $(\mathrm{AE}=16.3 \pm 4.0 \%)$. Estimated $\mathrm{AE}$ of ${ }^{54} \mathrm{Mn}$ also varied with the diet, though to a lesser extent. AE was significantly lower $(\mathrm{p}<0.001$, Table 5$)$ when turbot were fed with fish ( $\mathrm{AE}=23.0 \pm 7.7 \%)$ than when fed with shrimp and ragworms $(42.0 \pm 6.6 \%$ and $43.7 \pm 2.3 \%$, respectively; Fig. 3, Table 5). Variation of ${ }^{65} \mathrm{Zn} \mathrm{AE}$ was less pronounced. The only significant difference occurred for AEs estimated when turbot were fed with shrimp and ragworm $(\mathrm{p}<0.05$, Table 5$),{ }^{65} \mathrm{Zn}$ being more efficiently 
assimilated from shrimp $(\mathrm{AE}=32.2 \pm 6.0 \%)$. Regarding depuration rate constants $\left(\mathrm{k}_{\mathrm{es}}\right)$, values obtained for ${ }^{57} \mathrm{Co}$ and ${ }^{65} \mathrm{Zn}$ when fish were fed with ragworm were significantly higher $(\mathrm{p}<0.05)$ than when fed with the two other prey, indicating that their retention was shorter. For ${ }^{54} \mathrm{Mn}$, no significant difference of $\mathrm{k}_{\mathrm{es}}$ was observed $(\mathrm{p}>0.05$, Table 5$)$.

\subsection{Outputs of the model on metal intake}

The relative contributions of the different prey in the daily trophic intake of stable metal in turbot under three natural diets are shown in Figure 4. When the diet of turbot was composed of fish and crustaceans, the latter taxon provided the highest essential element intake (Fig. 4A and 4B). However, when polychaetes were included in the diet (even in small proportion, viz. 28\%), they contributed to the largest proportion of Co and $\mathrm{Mn}(38-58 \%$ and $40-78 \%$, respectively, depending on the scenario; Fig. 4C).

\section{Discussion}

Our results show that assimilation efficiencies (AEs) are metal-dependent and affected by the food items. Ranges of $\mathrm{AE}$ of ${ }^{57} \mathrm{Co},{ }^{54} \mathrm{Mn}$ and ${ }^{65} \mathrm{Zn}$ in turbot for the three different prey considered were respectively $5-43 \%, 23-44 \%$, and $17-32 \%$. Although, trophic transfer of Co and $\mathrm{Mn}$ is poorly documented in fish, information available show that AEs or remaining activities (multifeeding experiments) reported for the carp Cyprinus carpio (Baudin \& Fritsch 1989), the rainbow trout Oncorhynchus mykiss (Baudin et al. 2000), the silversides Menidia sp. (Reinfelder \& Fisher 1994) and the turbot S. maximus (Mathews et al. 2008) are always lower than the ones

determined in the present study. The values obtained for ${ }^{65} \mathrm{Zn}$ are in accordance with the literature on marine and brackish fish fed with zooplankton (Ni et al. 2000; Xu \& Wang 2002; 
Zhang \& Wang 2005) or juvenile fish (Mathews et al. 2008) where reported AEs were between $5 \%$ and $31 \%$. To the best of our knowledge, effect of food type on AE of Co and Mn has never been studied in fish. However, several studies have demonstrated that $\mathrm{AE}$ of $\mathrm{Zn}$ in a predator fish can be affected by the food composition. For example, changes in AE were reported for the glassy Ambassis urotaenia (AE between 9 to 15\%) and the mudskipper Periophthalmus cantonensis (AE between 11 to 31\%) when respectively fed with Artemia sp. and Acartia spinicauda (Ni et al. 2000). According to these authors, differences in AE would be explained by metal storage in specific locations in the prey and would explain the tight correlation observed between $\mathrm{AE}$ and elemental distribution in the soft tissues of zooplankton prey.

It is well documented that storage forms and location of metals in prey determine the bioavailability of these elements for predators (e.g. Wallace and Lopez, 1996; Wallace and Luoma, 2003; Meyer et al. 2005) and impact the AE. In order to investigate the possible relationship between storage or location of $\mathrm{Co}, \mathrm{Mn}$ and $\mathrm{Zn}$ in the prey and the $\mathrm{AE}$ of these elements in turbot, the measured $\mathrm{AE}$ were compared with metal distribution in the prey determined by the following methods (1) dissection (tissue distribution) and (2) ultracentrifugation (i.e. subcellular distribution, i.e. soluble vs. insoluble fraction). Several hypotheses examined to explain the relationship between the bioavailability of metals, their fractioning in prey and their assimilation in predators (Rainbow et al. 2011). Our results, obtained using complex pluricellular prey, were compared with the two main hypotheses often reported in the recent scientific literature for organisms fed with unicellular or simple pluricellular prey. The first hypothesis assumes that $\mathrm{AE}$ of the predator can be estimated from the percentage of metal in the non-exoskeleton fraction, or soft body parts of the prey (Reinfelder and Fisher 1994). Such a relationship has been reported for ${ }^{109} \mathrm{Cd},{ }^{57} \mathrm{Co},{ }^{75} \mathrm{Se}$, and ${ }^{65} \mathrm{Zn}$ in the silversides Menidia menidia 
and M. beryllina fed with zooplankton. The second hypothesis assumes that the proportion of bioavailable metals for predators is related to the quantity of metal associated to the cytosolic fraction of the prey (Fig. 1; Wallace \& Lopez 1996). Metal available fraction was further considered to be better reflected if the fraction of the metal associated with organelles was added to the cytosolic fraction (i.e. concept of Trophic Available Metal -TAM-; Wallace and Luoma, 2003). In the case of metal bioavailability to predatory fish, Zhang and Wang (2006) found a positive relationship between TAM fraction in a variety of prey organisms (barnacles, bivalves, fish viscera and zooplankton) and AE of $\mathrm{Zn}$ and $\mathrm{Se}$ in the grunt Terapon jarbua. Nevertheless, no strict equivalence between $\mathrm{TAM}$ in prey and $\mathrm{AE}$ in fish has been found yet, in contrast to invertebrates, while the determination of metal available fraction from one trophic level to another is still intensely studied or discussed in the scientific literature (e.g. Rainbow et al. 2011; Rainbow et al. 2015).

In the present study, no clear relationship was detected between AEs and metal fractioning in the prey either at a tissue (dissection) or subcellular (ultracentrifugation) level (Fig. 2A and B).. Therefore, our results do not support the hypotheses of Reinfelder and Fisher (1994) and of Wallace and Lopez (1996) in the case of turbot fed with complex pluricellular prey. Indeed, for $\mathrm{Co}$ and $\mathrm{Zn}$, values of $\mathrm{AE}$ for predator were lower than those expected from both hypotheses, which advocate for its equivalence with metal fraction in the soft parts of the prey (Figs 1A and 2A) or metal soluble fraction in the prey (Fig. 2B). A fraction of Co and $\mathrm{Zn}$ contained in the supposed bioavailable compartments of prey (i.e. soft tissues and soluble fraction) was not assimilated by the turbot (Figs 1B, 2A and 2B). This overestimation of the bioavailable fraction of trace elements by measuring metals in the cytosolic fraction, indicates that the "TAM fraction" is not applicable to assess the trophically available fractions of $\mathrm{Co}$ and $\mathrm{Mn}$ in a natural prey of the 
turbot (Fig. 1A). One potential explanation could result from the ecology of turbot. Indeed, the optimal temperature of juvenile turbot (approx. $15^{\circ} \mathrm{C}$ as used in the present study) is lower than the examples mentioned previously (Menidia sp. and Terapon jarbua, respectively raised at 18 and $20^{\circ} \mathrm{C}$ ). Acknowledging the positive relationship between temperature and the activity of the digestive enzymes in fish (Xiong et al. 2011), low temperature may lead to a low enzyme activity in turbot, resulting in a less efficient digestion of food and thus lower AEs than expected.

Interestingly, Mn was the only essential element for which AE was found to be greater than what was expected by theory (Fig. $1 \mathrm{C}$ and $2 \mathrm{~B}$ ), when the turbot were fed with shrimp or fish. In this specific case, the cytosolic fraction underestimated the fraction of the prey assimilated by the turbot $(\%$ soluble $<\mathrm{AE})$. Therefore the TAM theory (that adds the fraction in the organelles to the fraction present in the cytosol) may be relevant (Fig. 1) although our results cannot prove the equivalence of TAM and AE. Alternatively our data suggests that other insoluble subcellular compartments of the prey found in the soft tissues (i.e., compare Fig. 2A and 2B) can be assimilated by the turbot (Fig. 1). For example, previous studies using invertebrate predators (i.e. two neogastropods fed with various species of molluscs and crustaceans) have shown that a part of the metal assimilated from the food was also associated to "metal rich-granules" and "cellular debris" of the prey (Cheung \& Wang 2005; Rainbow et al. 2007). Indeed, metals bound in metalrich granules (MRG) appear to be more susceptible to the "assimilatory powers" of neogastropod molluscs than those of other invertebrates like decapod crustaceans (Wallace \& Lopez 1997; Wallace \& Luoma 2003; Rainbow et al. 2006; Rainbow et al. 2011). In this context, further studies are needed to assess which parts of insoluble fraction compartments (which include organelles, cellular debris and MRG; Fig. 1A) must be taken into account to assess accurately the trophically available fraction of $\mathrm{Mn}$ in a predator fish like the turbot. 
Our results obtained in controlled conditions help understand the influence of diet on metal AEs. They also provide preliminary information on the contribution of each prey to the total intake of essential metals per ration in the fish, when taking into account the variation of natural diet assessed in the field. The natural diet of the juvenile turbot is mainly composed of crustaceans (in particular decapods), fish (mostly adults and larvae of small pelagic species; Fig. 4) and eventually polychaetes, although their relative proportion is variable and habitat- and seasondependent (Sparrevohn et al. 2008; Florin \& Lavados 2010). When combining our results from radiotracer experiments and the level of stable elements measured in typical prey, we estimate that, although polychaetes (ragworms) represent only $28 \%$ of the stomach contents of turbot, they contribute $38-58 \%$ and $40-78 \%$ to the total intake of Co and Mn respectively in the "Low" and "High" scenarios (Table 2, Fig 4C). Ragworms tend to concentrate metals in the marine environment (Table 4). Our results confirmed other field investigations (see reviews of Eisler 2009a, b) and showed higher concentrations of Co, Mn and $\mathrm{Zn}$ in polychaetes than fish and crustaceans. In the case of $\mathrm{Mn}$, the high contribution of polychaetes can be explained by the high Mn AE observed in turbot fed with ragworms. On the other hand, these turbot poorly assimilated Co and the contribution of polychaetes was related to the high concentration of stable Co in this species. Another aspect revealed by our assessment is the limited contribution of fish to the intake of $\mathrm{Zn}$ (always $<24 \%$ ) despite the fact that this prey can represent up to $36 \%$ of stomach contents of juvenile turbot (Fig. 4B). Shrimp generally provide a major part of the essential elements from food and are also the prey that have the highest protein level (Table 3), highlighting the nutritional and ecological importance of crustaceans in the diet of the turbot. 


\section{Conclusion}

This study provides new information on essential element assimilation in a marine fish. Our results suggest that diet composition plays a significant role in the assimilation of essential elements ingested with food in the turbot $S$. maximus. It also highlights that the supposed relationships between $\mathrm{AE}$ in predator and metal fractioning in prey are not necessarily confirmed when complex pluricellular food items are considered. Our simple model, based on the relative contribution of the different prey to essential metal uptake, emphasizes the importance of crustaceans in the nutrition of turbot although when seasonally available polychaetes can make a disproportionately high contribution to dietary Co and Mn uptake by turbot

\section{Acknowledgments}

We thank the three anonymous reviewers for their very useful comments. Authors are grateful to S. Azemard, E. Vasileva-Veleva (MESL, IAEA) and B. Gasser (REL, IAEA) for their help respectively on stable metal and $\mathrm{CHN}$ analysis. MW is an Honorary Senior Research Associate of the National Fund for Scientific Research (NFSR, Belgium). The IAEA is grateful for the support provided to its Environment Laboratories by the Government of the Principality of Monaco. 


\section{Literature cited}

Baudin JP, Adam C, Garnier-Laplace J (2000) Dietary uptake, retention and tissue distribution of ${ }^{54} \mathrm{Mn},{ }^{60} \mathrm{Co}$ and ${ }^{137} \mathrm{Cs}$ in the rainbow trout (Oncorhynchus mikiss Walbaum). Water Res $34: 2869-2878$

Baudin JP, Fritsch AF (1989) Relative contributions of food and water in the accumulation of ${ }^{60}$ Co by a freshwater fish. Water Res $23: 817-823$

Biomar (2014) Turbot (Scophtalmus maximus). www.biomar.com/en/BioMar-France/Speciesand-products/Turbot (accessed 13 Nov 2014)

Boyden CR (1974) Trace element content and body size in molluscs. Nature 251:311-314

Bruland KW (1983) Trace elements in seawater. In: Riley, J.P., Chester, R., (eds) Chemical oceanography, Academic Press, New-York, p 157-220

Bury NR, Walker PA, Glover CN (2003) Nutritive metal uptake in teleost fish. J Exp Biol 206:11-23

Bustamante P, Miramand P (2005) Subcellular and body distributions of 17 trace elements in the variegated scallop Chlamys varia from the French coast of the Bay of Biscay. Sci Total Environ 337:59-73

Cheung M, Wang W-X (2005) Influence of subcellular metal compartmentalization in different prey on the transfer of metals to a predatory gastropod. Mar Ecol Prog Ser 286:155-166

Dutton J, Fisher NS (2011) Bioaccumulation of As, Cd, Cr, $\mathrm{Hg}(\mathrm{II})$, and $\mathrm{MeHg}$ in killifish (Fundulus heteroclitus) from amphipod and worm prey. Sci Total Environ 409:34383447

Eisler R (2009a) Compendium of trace metals and marine biota: Volume 1: Plants and invertebrates. Elsevier, Amsterdam

Eisler R (2009b) Compendium of trace metals and marine biota: Volume 2: Vertebrates. Elsevier, Amsterdam

Florin A-B, Lavados G (2010) Feeding habits of juvenile flatfish in relation to habitat characteristics in the Baltic Sea. Estuar Coast Shelf Sci 86:607-612

Förstner U, Wittmann GTW (1983) Metal pollution in the aquatic environment, 2nd edition. Springer, Berlin 
Garnier-Laplace J, Adam C, Baudin JP (2000) Experimental kinetic rates of food-chain and waterborne radionuclide transfer to freshwater fish: A basis for the construction of fish contamination charts. Arch Environ Contam Toxicol 39:133-144

Hédouin L, Metian M, Teyssié J-L, Fowler SW, Fichez R, Warnau M (2006) Allometric relationships in the bioconcentration of heavy metals by the edible tropical clam Gafrarium tumidum. Sci Total Environ 366:154-163

Lall SP, Lewis-McCrea LM (2007) Role of nutrients in skeletal metabolism and pathology in fish: An overview. Aquaculture 267:3-19

Mathews T, Fisher NS (2009) Dominance of dietary intake of metals in marine elasmobranch and teleost fish. Sci Total Environ 407:5156-5161

Mathews T, Fisher NS, Jeffree RA, Teyssié J-L (2008) Assimilation and retention of metals in teleost and elasmobranch fishes following dietary exposure. Mar Ecol Prog Ser 360:1-12

Metian M, Hédouin L, Eltayeb MM, Lacoue-Labarthe T, Teyssié J-L, Mugnier C, Bustamante P, Warnau M (2010) Metal and metalloid bioaccumulation in the Pacific blue shrimp Litopenaeus stylirostris (Stimpson) from New Caledonia: Laboratory and field studies. Mar Pollut Bull 61:576-584

Meyer JS, Adams WJ, Brix KV, Luoma SN, Mount DR, Stubblefield WA, Wood CM (2005) Toxicity of dietborne metals to aquatic organisms. Society of Environmental Toxicology and Chemistry, Pensacola, FL

Ni IH, Wang WX, Tam YK (2000) Transfer of Cd, Cr and Zn from zooplankton prey to mudskipper Periophthalmus cantonensis and glassy Ambassis urotaenia fishes. Mar EcolProg Ser 194:203-210

Rainbow PS, Amiard JC, Amiard-Triquet C, Cheung MS, Zhang L, Zhong H, Wang WX (2007) Trophic transfer of trace metals: subcellular compartmentalization in bivalve prey, assimilation by a gastropod predator and in vitro digestion simulations. Mar Ecol Prog Ser 348:125-138

Rainbow PS, Liu F, Wang W-X (2015) Metal accumulation and toxicity: the critical accumulated concentration of metabolically available zinc in an oyster model. Aquat Toxicol Amst Neth 162:102-108

Rainbow PS, Luoma SN, Wang W-X (2011) Trophically available metal: A variable feast. Environ Pollut 159:2347-2349 
Rainbow PS, Poirier L, Smith BD, Brix KV, Luoma SN (2006) Trophic transfer of trace metals: subcellular compartmentalization in a polychaete and assimilation by a decapod crustacean. Mar Ecol Prog Ser 308:91-100

R Development Core Team (2014) R: A language and environment for statistical computing. R Foundation for Statistical Computing, Vienna, Austria

Reinfelder JR, Fisher NS (1994) Retention of elements absorbed by juvenile fish (Menidia menidia, Menidia beryllina) from zooplankton prey. Limnol Oceanogr 39:1783-1789

Rodriguez y Baena AM, Metian M, Teyssié J-L, De Broyer C, Warnau M. (2006) Experimental evidence for ${ }^{234} \mathrm{Th}$ bioaccumulation in three Antarctic crustaceans: Potential implications for particle flux studies. Mar. Chem. 100:354-365.

Simkiss K (1979) Metal ions in cells. Endeavour 3:2-6

Sparrevohn CR, Støttrup J (2008) Diet, abundance and distribution as indices of turbot (Psetta maxima L.) release habitat suitability. Rev Fish Sci 16:338-347

Tacon AGC, Metian M, Hasan MR (2009) Feed ingredients and fertilizers for aquatic animals: sources and composition. Food and Agriculture Organization of the United Nations, Rome

Wallace WG, Lopez GR (1996) Relationship between subcellular cadmium distribution in prey and cadmium trophic transfer to a predator. Estuaries 19:923-930

Wallace W, Lopez G (1997) Bioavailability of biologically sequestered cadmium and the implications of metal detoxification. Mar Ecol Prog Ser 147:149-157

Wallace WG, Luoma SN (2003) Subcellular compartmentalization of Cd and $\mathrm{Zn}$ in two bivalves. II. Significance of trophically available metal (TAM). Mar Ecol Prog Ser 257:125-137

Wang W-X, Fisher NS (1999) Assimilation efficiencies of chemical contaminants in aquatic invertebrates: A synthesis. Environ Toxicol Chem 18:2034-2045

Warnau M, Bustamante P (2007) Radiotracer techniques: A unique tool in marine ecotoxicological studies. Environ Bioindic 2:217-218

Warnau M, Ledent G, Temara A, Alva V, Jangoux M, Dubois P (1995) Allometry of heavy metal bioconcentration in the echinoid Paracentrotus lividus. Arch Environ Contam Toxicol 29:393-399 
Warnau M, Teyssié J-L, Fowler SW (1996) Biokinetics of selected heavy metals and radionuclides in the common Mediterranean echinoid Paracentrotus lividus: Sea water and food exposures. Mar Ecol Prog Ser 141:83-94

Williams RJP (1981) The Bakerian Lecture, 1981: Natural selection of the chemical elements. Proc R Soc Lond B Biol Sci 213:361-397

Xiong DM, Xie CX, Zhang HJ, Liu HP (2011) Digestive enzymes along digestive tract of a carnivorous fish Glyptosternum maculatum (Sisoridae, Siluriformes). J Anim Physiol Anim Nutr 95:56-64

Xu Y, Wang WX (2002) Exposure and potential food chain transfer factor of Cd, Se and Zn in marine fish Lutjanus argentimaculatus. Mar Ecol Prog Ser 238:173-186

Zhang L, Wang W-X (2005) Effects of Zn pre-exposure on Cd and Zn bioaccumulation and metallothionein levels in two species of marine fish. Aquat Toxicol 73:353-369

Zhang L, Wang W-X (2006) Significance of subcellular metal distribution in prey in influencing the trophic transfer of metals in a marine fish. Limnol Oceanogr 51:2008-2017 


\section{A - According to the theories}

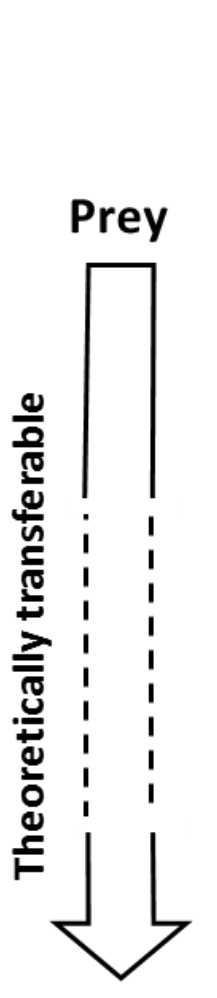

Predator
Whole-body metal burden in the prey

INSOLUBLE FRACTION

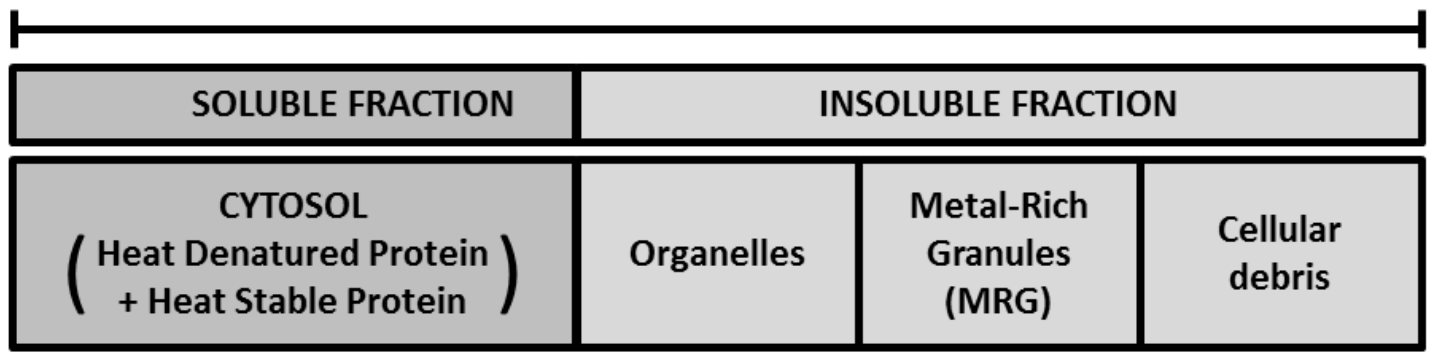

1 - From Wallace and Lopez (1996)

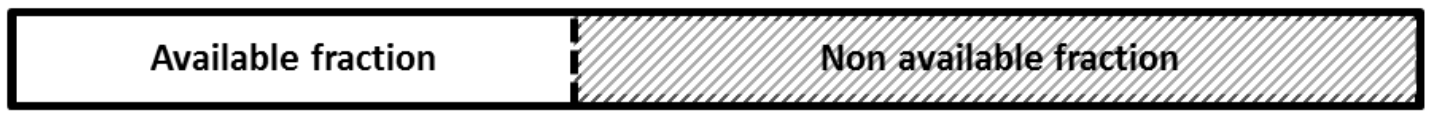

2 - From Wallace and Luoma (2003)

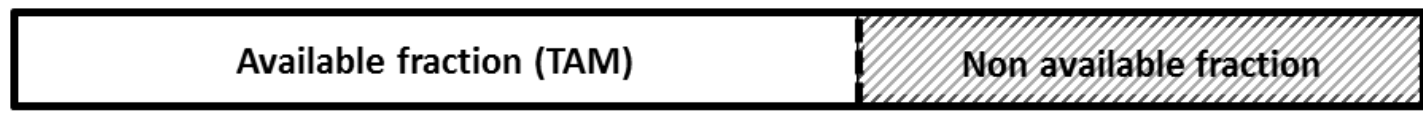

Correspondence to the storage in the prey ?
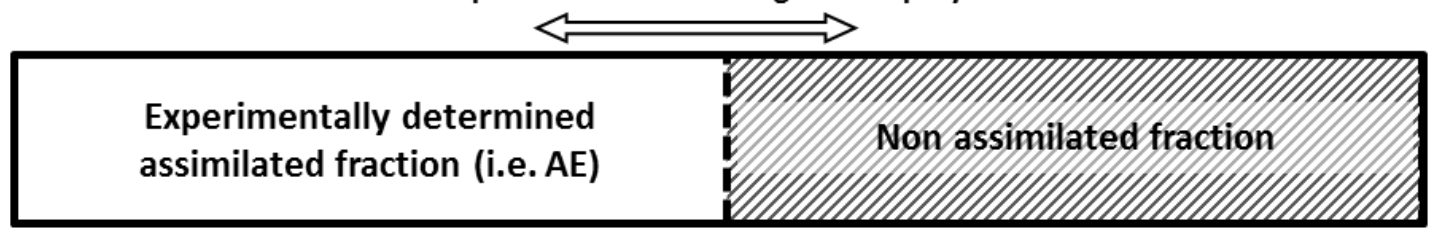

\section{B - For Co and Zn}
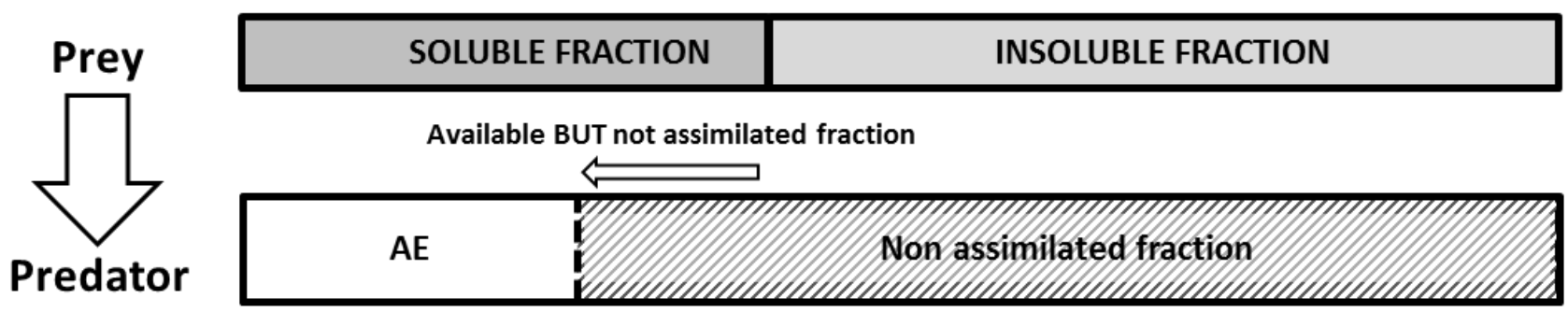

\section{C - For $\mathrm{Mn}$}

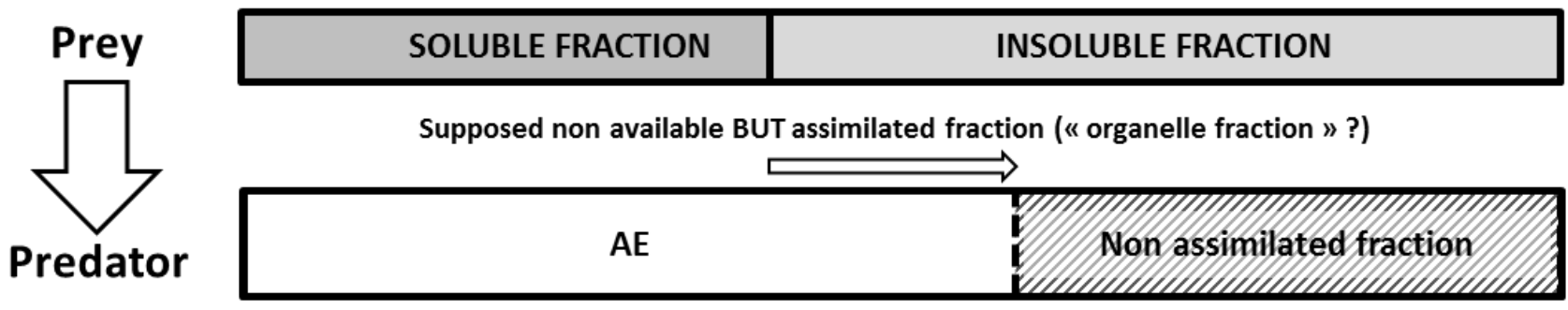

Figure 1. Definition of the different concepts used in metal's subcellular fractionation and relation between subcellular fractionation in the prey and assimilation efficiency measured in predator. (A) Description of theories developed by Wallace and Lopez (1996) and Wallace and Luoma (2003). (B) The present study where measured AE in the predator is lower than expected values on the basis of fraction of element present in the soluble fraction - part of metal available fraction in the prey is not assimilated by the predator. (C) The present study where measured AE in the predator is higher than expected values on the basis of fraction of element present in the soluble fraction - part of non-available metal fraction in the prey is assimilated by the predator. 

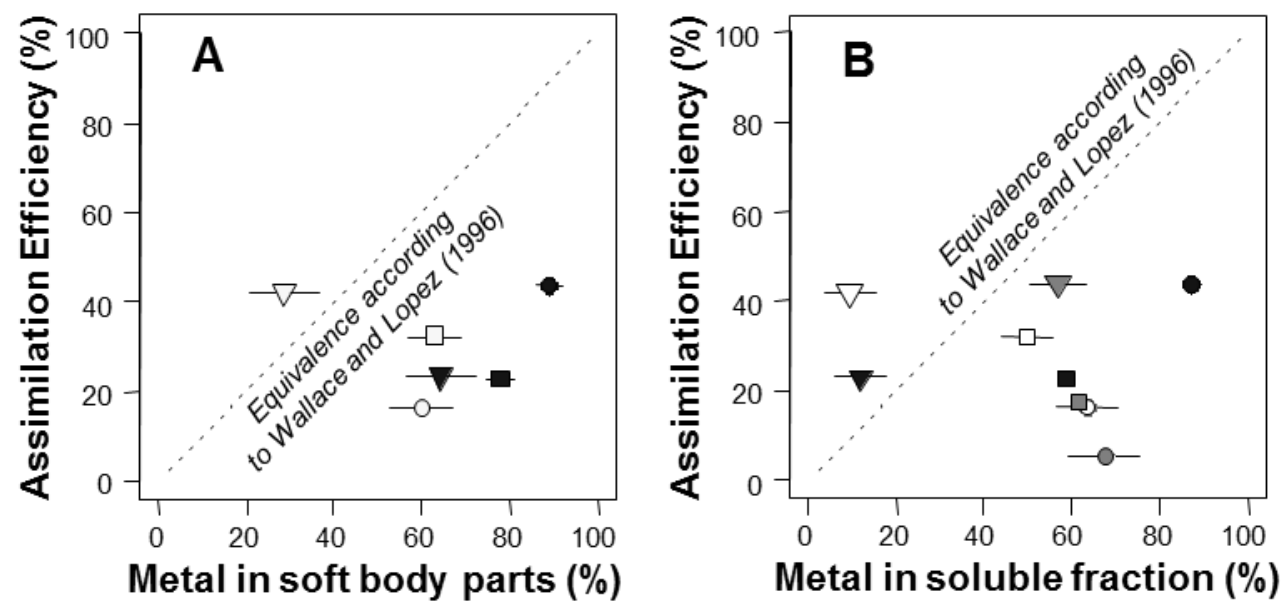

Figure 2. Relationship between metal fractioning in the prey (quantify by dissection and centrifugation) and Assimilation Efficiency (AE) in turbot. (A) Comparison between $\mathrm{AE}$ and metals: Mn (triangle), Co (circle) and Zn (square), included in soft body parts of fish in black and shrimp in white. (B) Comparison between AE in turbot and metals in soluble fractions of fish in black, shrimp in white and ragworm in grey. 

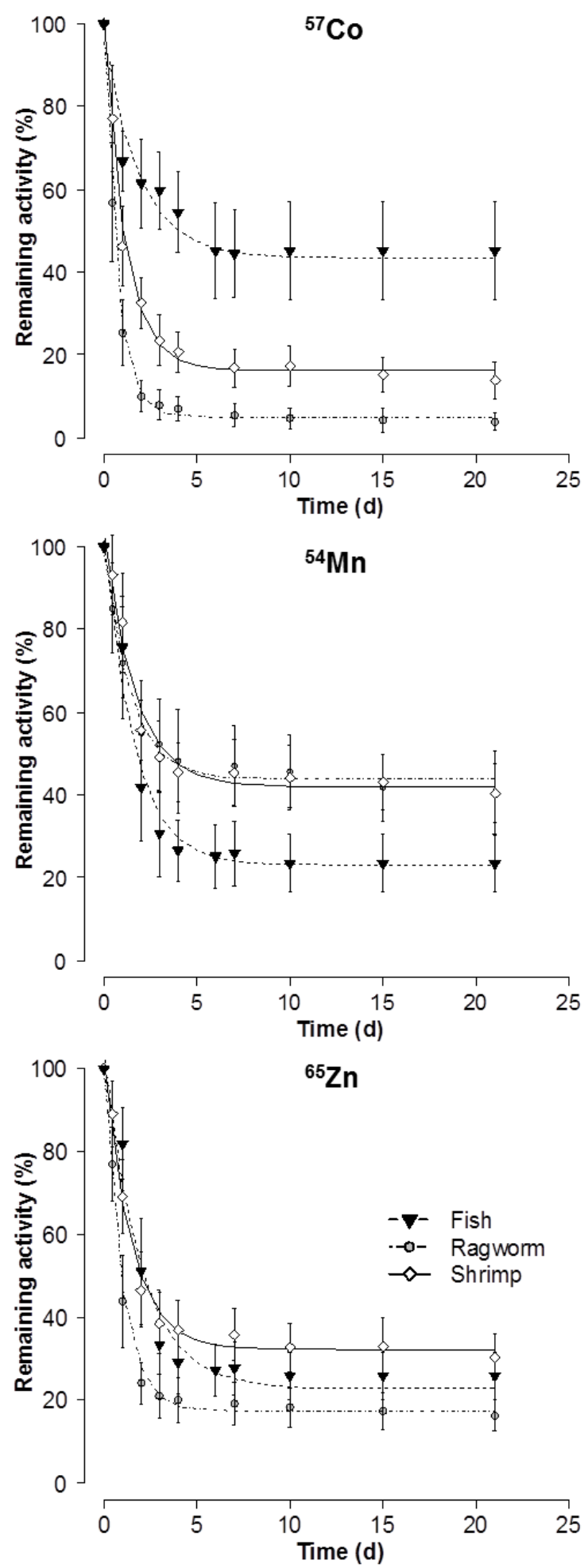

Figure 3. Influence of type of food (see Table 2) on whole-body depuration of ${ }^{57} \mathrm{Co},{ }^{54} \mathrm{Mn}$ and ${ }^{65} \mathrm{Zn}$ in turbot (\% remaining activities, means \pm SD). Parameters and statistics of depuration kinetics are given in Table 4. 

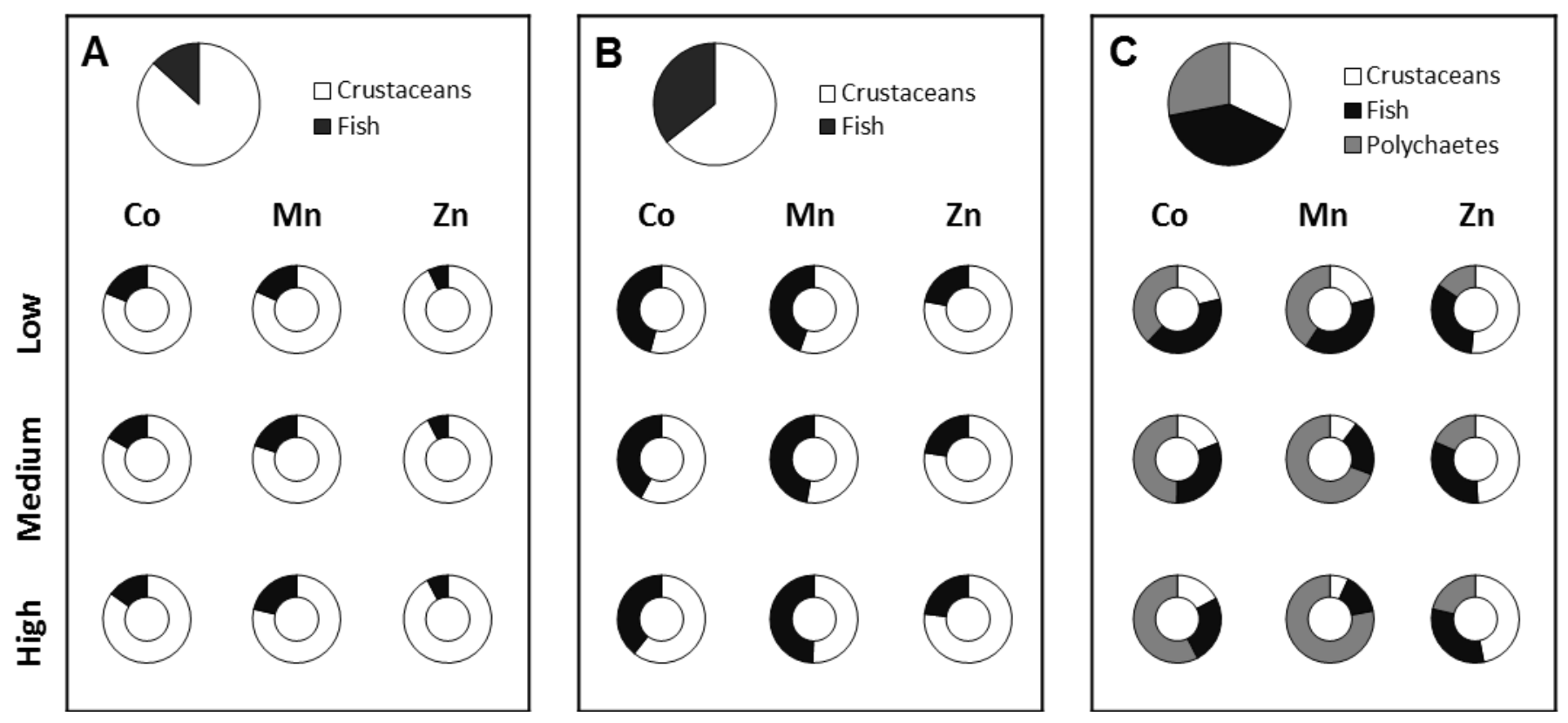

Figure 4. Relative contribution of the different prey in the daily intake of stable metal from food in turbot under three natural diets. Three different scenarios were considered to reflect the variability of parameter's values. Scenario "Low" takes into account lower concentration values of metals in prey with a low ingestion rate and reduced assimilation. Conversely, in the scenario "High", we considered the maximum values of these parameters. Finally, the average values were used in the "Medium" scenario. 
Table 1. Comparison of metal concentration (mean $\pm \mathrm{SD}, \mathrm{n}=3$ ) in reference material (fish muscle, IAEA 407) measured by ICP-MS (Co and $\mathrm{Mn}$ ) and by flame atomic absorption spectrometry $(\mathrm{Zn})$ with certified values. All the values are expressed in $\mu \mathrm{g} \cdot \mathrm{g}^{-1} \mathrm{dwt}$.

\begin{tabular}{lll}
\hline Element & Measured & Certified \\
\hline Co & $0.08 \pm 0.01$ & $0.10 \pm 0.02$ \\
$\mathrm{Mn}$ & $2.50 \pm 0.07$ & $3.52 \pm 0.32$ \\
$\mathrm{Zn}$ & $65.4 \pm 0.7$ & $67.1 \pm 3.8$ \\
\hline
\end{tabular}


Table 2. Food composition and nutritional values (mean $\pm \mathrm{SD}$ ). For the shrimps, antennae, antennules, rostrum and telson were removed.

\begin{tabular}{|c|c|c|c|c|c|}
\hline \multirow{2}{*}{ Composition } & \multirow{2}{*}{ Fish } & \multicolumn{3}{|l|}{ Shrimp } & \multirow{2}{*}{ Ragworm } \\
\hline & & Cephalothorax & Abdomen & $\begin{array}{l}\text { Whole } \\
\text { (reconstituted) }\end{array}$ & \\
\hline Dry matter (DM \%) & $22.2 \pm 3.19$ & $29.03 \pm 0.43$ & $27.1 \pm 0.82$ & $27.9 \pm 0.63$ & $20.6 \pm 1.96$ \\
\hline \multicolumn{6}{|l|}{ Stable metals } \\
\hline $\operatorname{Co}\left(\mu g^{-1} d w t\right)$ & $0.11 \pm 0.01$ & $0.12 \pm 0.03$ & $0.04 \pm 0.00$ & $0.08 \pm 0.01$ & $2.21 \pm 0.82$ \\
\hline $\operatorname{Mn}\left(\mu \mathrm{g} \mathrm{g}^{-1} \mathrm{dwt}\right)$ & $15.8 \pm 1.75$ & $2.78 \pm 0.28$ & $1.34 \pm 0.12$ & $2.02 \pm 0.09$ & $43.06 \pm 31.33$ \\
\hline $\mathrm{Zn}\left(\mu \mathrm{g} \mathrm{g}^{-1} \mathrm{dwt}\right)$ & $110 \pm 1$ & $71 \pm 3$ & $43 \pm 1$ & $56 \pm 1$ & $127 \pm 25$ \\
\hline \multicolumn{6}{|l|}{ Nutritional values } \\
\hline Nitrogen $(\mathrm{N}, \% \mathrm{DM})$ & $2.19 \pm 0.07$ & $2.72 \pm 0.44$ & $3.09 \pm 0.30$ & $2.93 \pm 0.35$ & $0.89 \pm 0.59$ \\
\hline Protein $(\% \mathrm{DM}) *$ & $12.2 \pm 0.40$ & $15.25 \pm 2.44$ & $17.32 \pm 1.68$ & $16.44 \pm 1.94$ & $4.99 \pm 3.31$ \\
\hline
\end{tabular}

* Estimation based on nitrogen content using conversion coefficients (5.58 for fish and 5.6 for the other prey; Tacon et al. 2009) 
Table 3. Description of the 3 scenarios used in the model for estimating the relative contribution of prey in the essential metal's intakes of turbot and details on the values used for the variables. The variables in these scenarios are the assimilation efficiency of predator (AE), the ingestion rate of predator (IR) and stable metal concentration in the prey (Q).

\begin{tabular}{llll}
\hline \multirow{2}{*}{ Parameters } & \multicolumn{2}{l}{ Scenario } & \\
\cline { 2 - 4 } & Low & Medium & High \\
\hline AE (assimilation efficiency of predator) & Mean - SD & Mean & Mean + SD \\
IR (ingestion rate of predator) & Min & Mean & Max \\
Q (stable metal concentration in the prey) & Mean - SD & Mean & Mean + SD \\
\hline
\end{tabular}


Table 4. Estimated depuration kinetic parameters of ${ }^{57} \mathrm{Co},{ }^{54} \mathrm{Mn}$ and ${ }^{65} \mathrm{Zn}$ in turbot exposed to the radiotracers by 3 different types of food $(n=8-12$ per treatment) and then maintained for $21 \mathrm{~d}$ in unspiked seawater. $k_{e s}$ : depuration rate constant $\left(d^{-1}\right) ; T_{b^{1 / 2 s}}$ : biological half-life $(d)$, AE: assimilation efficiency (\%); ASE: asymptotic standard error; $\mathrm{R}^{2}$ : determination coefficient. Probability of the model adjustment: * $\mathrm{p}<0.05, * * \mathrm{p}<0.01, * * * \mathrm{p}<0.001$.

\begin{tabular}{|c|c|c|c|c|c|}
\hline \multirow{2}{*}{ Tracer } & \multirow{2}{*}{ Feed } & \multicolumn{2}{|l|}{ Short-term } & \multicolumn{2}{|l|}{ Long-term } \\
\hline & & $\mathrm{k}_{\mathrm{es}} \pm \mathrm{ASE}$ & $\mathrm{T}_{\mathrm{b}^{1 / 2 s}} \pm \mathrm{ASE}$ & $\mathrm{AE} \pm \mathrm{ASE}$ & \\
\hline \multirow[t]{3}{*}{${ }^{57} \mathrm{Co}$} & Fish & $0.52 \pm 0.10 * * *$ & $1.33 \pm 0.24$ & $43.46 \pm 1.94 * * *$ & 0.76 \\
\hline & Shrimp & $0.87 \pm 0.05^{* * *}$ & $0.79 \pm 0.05$ & $16.30 \pm 0.92 * * *$ & 0.97 \\
\hline & Ragworm & $1.43 \pm 0.07 * * *$ & $0.48 \pm 0.02$ & $5.04 \pm 0.78 * * *$ & 0.98 \\
\hline \multirow[t]{3}{*}{${ }^{54} \mathrm{Mn}$} & Fish & $0.63 \pm 0.05^{* * *}$ & $1.10 \pm 0.09$ & $23.10 \pm 1.47 * * *$ & 0.88 \\
\hline & Shrimp & $0.61 \pm 0.05^{* * *}$ & $1.14 \pm 0.09$ & $41.99 \pm 1.20 * * *$ & 0.93 \\
\hline & Ragworm & $0.71 \pm 0.10 * * *$ & $0.98 \pm 0.14$ & $43.79 \pm 1.62 * * *$ & 0.89 \\
\hline \multirow[t]{3}{*}{${ }^{65} \mathrm{Zn}$} & Fish & $0.51 \pm 0.04 * * *$ & $1.35 \pm 0.12$ & $22.80 \pm 1.63^{* * *}$ & 0.94 \\
\hline & Shrimp & $0.69 \pm 0.04 * * *$ & $1.00 \pm 0.03$ & $32.20 \pm 1.00^{* * *}$ & 0.96 \\
\hline & Ragworm & $1.05 \pm 0.06^{* * *}$ & $0.66 \pm 0.04$ & $17.39 \pm 0.94 * * *$ & 0.97 \\
\hline
\end{tabular}


Table 5. Comparison of assimilation efficiency (AE, \%) and depuration rate constant $\left(k_{e s}, \mathrm{~d}^{-1}\right)$ of ${ }^{57} \mathrm{Co},{ }^{54} \mathrm{Mn}$ and ${ }^{65} \mathrm{Zn}$ in turbot exposed to the radiotracers by three different types of food $(\mathrm{n}=8$ 12 per treatment) and then maintained for $21 \mathrm{~d}$ in unspiked seawater. Underlines indicated that the values (means $\pm \mathrm{SD}$ ) are not significant different $(\mathrm{p}>0.05)$. Statistical comparisons between the three different feeding experiments were undertaken using individual depuration kinetics of each element: individual kinetic parameters ( $\mathrm{k}_{\mathrm{es}}$ and $\mathrm{AE}$ ) were obtained using the best fitting model at the global scale (Table 4) to the data of each individual.

\begin{tabular}{|c|c|c|c|c|}
\hline \multirow{2}{*}{ Parameter } & \multirow{2}{*}{ Tracer } & \multicolumn{3}{|l|}{ Prey } \\
\hline & & Fish & Shrimp & Ragworm \\
\hline \multirow[t]{3}{*}{$A E$} & ${ }^{57} \mathrm{Co}$ & $43.1 \pm 12.0$ & $16.28 \pm 4.04$ & $5.14 \pm 1.14$ \\
\hline & ${ }^{54} \mathrm{Mn}$ & $23.0 \pm 7.73$ & $\underline{41.99 \pm 6.61}$ & $43.17 \pm 2.34$ \\
\hline & ${ }^{65} \mathrm{Zn}$ & $21.7 \pm 6.85$ & $32.19 \pm 6.02$ & $17.94 \pm 1.92$ \\
\hline \multirow[t]{3}{*}{$k_{e s}$} & ${ }^{57} \mathrm{Co}$ & $0.59 \pm 0.24$ & $0.93 \pm 0.25$ & $1.57 \pm 0.10$ \\
\hline & ${ }^{54} \mathrm{Mn}$ & $0.69 \pm 0.21$ & $0.63 \pm 0.13$ & $0.78 \pm 0.16$ \\
\hline & ${ }^{65} \mathrm{Zn}$ & $0.53 \pm 0.10$ & $0.71 \pm 0.12$ & $1.02 \pm 0.12$ \\
\hline
\end{tabular}

